\title{
Liver-enriched transcription factor HNF-4 is a novel member of the steroid hormone receptor superfamily
}

\author{
Frances M. Sladek, Weimin Zhong, Eseng Lai, ${ }^{1}$ and James E. Darnell, Jr. \\ Laboratory of Molecular Cell Biology, Rockefeller University, New York, New York 10021 USA
}

\begin{abstract}
HNF-4 (hepatocyte nuclear factor 4) is a protein enriched in liver extracts that binds to sites required for the transcription of the genes for transthyretin (TTR), the carrier protein in the serum for vitamin A and thyroid hormone, and for apolipoprotein CIII (apoCIII), a major constituent of chylomicrons and very low-density lipoproteins (VLDL). Synthetic oligonucleotides derived from amino acid sequence of affinity-purified HNF-4 protein $(54 \mathrm{kD})$ were used in the polymerase chain reaction (PCR) to isolate a cDNA clone encoding the protein. HNF-4 is a member of the steroid hormone receptor superfamily with an unusual amino acid in the conserved "knuckle" of the first zinc finger (DGCKG). Studies with in vitro-translated HNF-4 protein show that it binds to its recognition site as a dimer, and cotransfection assays indicate that it activates transcription in a sequence-specific fashion in nonhepatic (HeLa) cells. Northern blot analysis reveals that HNF-4 mRNA is present in kidney and intestine, as well as liver, but is absent in other tissues. DNA-binding and antisera reactivity data suggest that HNF-4 could be identical to liver factor A1 (LF-A1), a DNA-binding activity implicated in the regulation of transcription of the $\alpha 1$-antitrypsin, apolipoprotein $\mathrm{Al}$, and pyruvate kinase genes. The similarity between HNF-4 and other ligand-dependent transcription factors raises the possibility that HNF-4 and the genes it regulates repond to an as yet unidentified ligand.
\end{abstract}

[Key Words: Hepatocyte; transthyretin; apolipoprotein CIII; LF-Al]

Received September 25, 1990; revised version accepted October 12, 1990.

Cell type specificity is based on differential gene expression, which is in turn determined, at least in part, by the particular set of transcription factors present and active in a given cell at a given time. Many such factors have been identified and characterized, particularly in the liver where there is a wide range of transcriptionally controlled genes (McKnight and Palmiter 1979; Derman et al. 1981|. Some transcription factors, such as AP-1 and Sp-1, seem to be present in all cells at all times, but other factors have a more limited distribution. Whether there is a discernible logic that explains the distribution of the many factors has yet to be determined. Two aspects of this problem are particularly important. First, is the distribution of factors in different tissues controlled at the level of transcription? If so, then a cascade of transcriptional regulation that ultimately results in cell specificity is indicated. Second, is any particular factor central to the accomplishment of a particular metabolic or physiologic goal? Such a goal might be suggested by a factor acting on an interrelated set of genes.

To illuminate these questions, the promoter/enhancer regions of genes expressed primarily in hepatocytes have been dissected and analyzed (for review, see Johnson

1Present address: Division of Endocrinology, Memorial Sloan-Kettering Cancer Center, New York, New York 10021 USA.
1990|. The DNA elements that confer cell-specific expression have been defined by transient transfection into cultured cells (e.g., hepatoma vs. HeLa cells) and/or in in vitro transcription assays, and the proteins that bind to these elements have been identified by DNA-binding assays using crude liver nuclear extracts. In this way, at least four distinct protein factors that are abundant in liver have been found thus far-HNF-1(LF-B1) (Courtois et al. 1987; Monaci et al. 1988); CCAAT/enhancer binding protein [C/EBP (Johnson et al. 1987)]; HNF-3 and HNF-4 (Costa et al. 1989); HNF-1, a homeo domain protein (Frain et al. 1989; Baumhueter et al. 1990); C/EBP, the original leucine zipper protein (Landschulz et al. 1988); and, most recently, HNF-3A, a DNA-binding protein that has no similarity to known transcription factor families (Lai et al. 1990) have all been purified and cloned so that distribution and regulation of each can be determined.

In this paper we present the purification and cloning of HNF-4 (hepatocyte nuclear factor 4), a factor originally detected in crude liver extracts as binding to a DNA element required for the transcription of the transthyretin (TTR) gene in hepatoma cells (Costa et al. 1989). Since then, the HNF-4-binding activity has been shown to bind a similar site in the promoter of the apolipoprotein CIII (apoCIII) gene (Costa et al. 1990). Amino 
acid sequence comparison indicates that HNF-4 is a member of the superfamily of steroid/thyroid hormone receptors, ligand-dependent transcription factors that are known to play a role in differentiation and development (for reviews, see Evans 1988; Green and Chambon 1988; Beato 1989). Whereas all of the other members to date fall into one of several subfamilies based on the amino acid sequence of the zinc finger region (Umesono and Evans 1989; Forman and Samuels 1990|, HNF-4 appears to represent a new subfamily.

\section{Results}

\section{Purification and characterization of HNF-4 protein}

Table 1 lists the different oligonucleotides used in the purification and characterization of the HNF-4 binding protein. Oligonucleotide -151 to -130 contains the HNF-4 site ( -151 to -140 ) required for TTR expression in transfection assays, as well as a weak HNF-3 site $(-130$ to -140$)$ (Costa et al. 1989); HNF4P is similar to -151 to -130 but does not contain the HNF-3 site; HNF4D is from a distal site in the TTR promoter lapproximately $-1.9 \mathrm{~kb}$ ), which was shown to enhance the transcription of TTR marginally (Costa et al. 1988, 1989) and is bound less well by protein in crude liver extracts than HNF4P. APFl and LF-Al (liver factor A1) are oligonucleotides derived from the promoter regions of the human apoCIII and $\alpha 1$-antitrypsin $(\alpha \mathrm{l}-\mathrm{AT})$ genes, respectively. Cross-competition studies done previously (Costa et al. 1990) showed that the factor that binds to the HNF-4 site in the TTR promoter also binds to the APF1 oligonucleotide.

HNF-4-binding protein was purified from rat liver nuclear extract by six chromatography steps, including two sequence-specific DNA affinity columns, one made with the HNF4P oligonucleotide and the other made with the APF1 oligonucleotide. Each step was assayed by the mobility-shift assay using a double-stranded probe (HNF4P or APF1). An SDS gel of the starting material of the last five columns plus the final purified fraction (fxn 38, Fig. 1A) showed a single Coomassie-stained band of $54 \mathrm{kD}$ nominal molecular mass that copurified with the mobility-shift activity. Elution and renaturation of protein from gel slices confirmed that the $54-\mathrm{kD}$ protein contained the sequence-specific DNA-binding activity (not shown). In one preparation, $\sim 700 \mathrm{mg}$ nuclear protein from 41 rats yielded $30-40 \mu \mathrm{g}$ of the $54-\mathrm{kD}$ protein with an overall recovery of $10-15 \%$ based on the mobilityshift activity. By comparing protein concentration and DNA-binding activity (APFl probe) for each step of the purification, the cumulative gain in specific activity was estimated to be 5000- to 10,000-fold.

The affinity column containing the apoCIII site, APF1 (oligo 2, Fig. 1A), was used in the purification scheme after the column with the TTR site, HNF4P /oligo 1, Fig. 1A). Therefore, to be certain that the final purified material still bound the TTR site, four different probes containing slightly different HNF-4 sites (APF1, -151 to -130, HNF4P, HNF4D) and three probes lacking sequence similarity to the HNF-4 recognition site $(-175$, HNF3, and C/EBP| were labeled to the same specific activity and tested in the mobility-shift assay with the purified protein. The purified material bound to all four HNF-4 sites and produced identical shift bands (Fig. 1B). The different relative affinities of the purified material for the various probes $\mid A P F 1>-151$ to $-130=$ HNF4P $>$ HNF4DI is the same as that found in crude liver nuclear extracts (not shown). As expected, the purified material did not bind to any of the unrelated oligonucleotides (Fig. 1B, lanes 9-14). To verify that the protein we purified was the one originally described by Costa et al. (1989), the purified protein was shown to footprint the region originally defined as the HNF-4 site in the TTR promoter, from -140 to -150 of the coding strand (gel not shown).

\section{Isolation of HNF-4 CDNA clones}

To isolate the cDNA encoding HNF-4 protein, a partial amino acid sequence of the protein purified from rat liver was obtained. Since the intact protein was found to be amino-terminally blocked, the purified material (Mono Q, fxn 38; $10 \mu \mathrm{g}$ ) was subjected to reverse-phase high-pressure liquid chromatography (HPLC), and the major peak, containing the $54-\mathrm{kD}$ protein, was cleaved with cyanogen bromide. The resulting peptides were separated by HPLC and sequenced.

Five peptide sequences were obtained (peptides 1-5). Sense $(S)$ and antisense (A) primers 23 nucleotides long with degeneracies ranging from 36 to 4096 were made to three of the peptides (peptides 1, 2, and 3). The primers were used in pairwise combinations (primers $1 \mathrm{~S}$ and $2 \mathrm{~A}$,

Table 1. Oligonucleotides used in this study

\begin{tabular}{|c|c|c|c|}
\hline & Gene & Sequence & Position \\
\hline-151 to -130 & TTR & $5^{\prime}$-TCGAGGCAAGGT TCATATTTGTGTAG-3' & -151 to -130 (mouse) \\
\hline HNF4P & TTR & 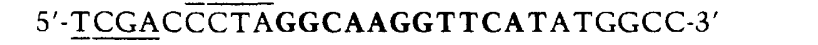 & -156 to -138 (mouse) \\
\hline HNF4D & TTR & 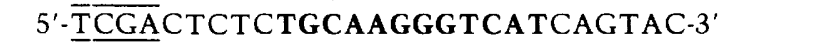 & $-1.86 \mathrm{~kb}$ (mouse) \\
\hline APF1 & apoCIII & $5^{\prime}$ - TCGAGCGCTGGGCAAAGGTCACCTGC-3' & -66 to -87 (human) \\
\hline LF-A1 & $\alpha 1-\mathrm{AT}$ & 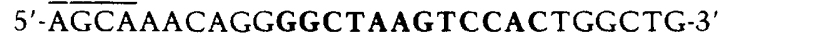 & -101 to -128 (human) \\
\hline \multirow[t]{2}{*}{ HNF- 4 consensus } & & GGCAAAGGTCAT & \\
\hline & & $\begin{array}{llllll}\mathbf{T} & \mathbf{T} & \mathbf{G} & \mathbf{T C} & \mathbf{C}\end{array}$ & \\
\hline
\end{tabular}

The sequence and origin of the top strand of the oligonucleotides used are given. The underlined nucleotides were added for convenience. Complementary bottom strands had 4-base overhangs at their $5^{\prime}$ ends. The boldface type highlights the region of consensus. 

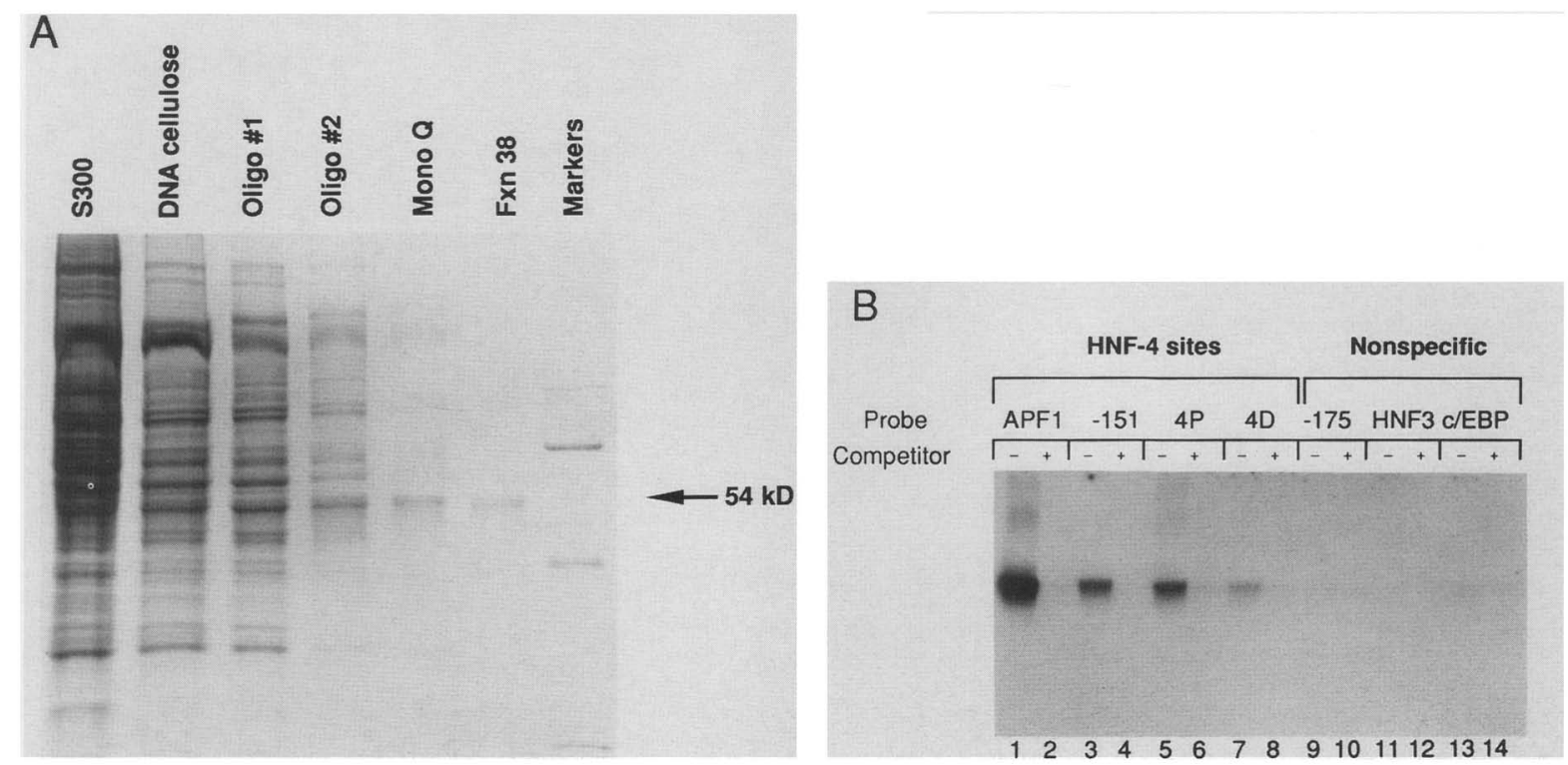

Figure 1. Purification and identification of HNF-4. (A) SDS-PAGE analysis of HNF-4 purification from rat liver nuclei. Equivalent fractions of the starting material for each of the five last chromatographic steps and the peak fraction from the Mono Q column (fxn 38 ) are shown in a Coomassie blue-stained gel. Oligonucleotides 1 and 2 are DNA affinity columns made from HNF4P and APF1 oligonucleotides, respectively. The band in fxn 38 was estimated to be $54 \mathrm{kD}$ based on the relative mobility of the markers $(97,66,43$, and $31 \mathrm{kD}$, top to bottom $).(B)$ Characterization of the binding activity of purified HNF-4 protein. The protein-DNA complexes from a mobility-shift assay $\left(0.0625 \mu \mathrm{l}\right.$ Mono Q fxn $38,3 \mu \mathrm{g} \mathrm{BSA}, 0.5 \mu \mathrm{g}$ poly[d(I-C)/ with seven ${ }^{32}$ P-labeled oligonucleotide probes (1 ng/ with and without 50 -fold excess competitor are shown. APF1; $(-151)-151$ to - 130; (4P) HNF4P; (4D) HNF4D as in Table 1 . Nonspecific probes are from the mouse TTR promoter: (- 175) TCGACCGATACTCTAATCTCCCTAGGC; (HNF3) - 111 to - 85 (Costa et al. 1989); (c/EBP) - $1.86 \mathrm{~kb}$, site 3 (Costa et al. 1988).

$1 \mathrm{~A}$ and $2 \mathrm{~S}$, etc.) in a polymerase chain reaction (PCR) with an amplified rat liver cDNA library as the template. Only the combinations of primers $1 \mathrm{~S}$ and $2 \mathrm{~A}$ and primers $3 \mathrm{~S}$ and $2 \mathrm{~A}$ resulted in products easily discernible by ethidium-bromide staining of an agarose gel (1.0 and $0.5 \mathrm{~kb}$, respectively). After subcloning and sequencing, the larger product $(1 \mathrm{~S}+2 \mathrm{~A})$ was found to contain the smaller product $(3 \mathrm{~S}+2 \mathrm{~A}$; Fig. $2 \mathrm{~A})$. The deduced amino acid sequence from the larger product also contained a region very similar to the two zinc fingers found in steroid hormone receptors. The shorter PCR product, which did not contain the zinc fingers, was used to screen $3.6 \times 10^{5}$ primary recombinants in the rat liver library. Of 22 positive clones at the second round of screening, 9 were fully characterized and found to be overlapping.

The partial nucleotide sequence of the largest cDNA insert (pf7, Fig. 2B) contains a long open reading frame (ORF) of $1365 \mathrm{bp}$ starting with an initiator methionine at nucleotide 59. There is another in-frame ATG codon beginning at nucleotide 32 , but comparison with the consensus sequence for translation initiation (GCCA/GCCATGG; Kozak 1987) and SDS-PAGE analysis of in vitro translation products (not shown) suggests that the ATG codon at nucleotide 59 is the major initiator for translation. All five peptide sequences derived from the purified HNF-4 protein appeared in the predicted amino acid sequence (Fig. 2B), confirming that the purified HNF-4 preparation did indeed contain only one major polypeptide. The 1365 -bp ORF encodes a protein
455 amino acids long with a molecular mass of $50.6 \mathrm{kD}$. The polyadenylation signal was not found.

A search of GenBank revealed that HNF-4 is a novel protein but that it has a structure analogous to that of the steroid/thyroid hormone receptors (Fig. 3). HNF-4 contains a region with two potential zinc fingers between amino acids 50 and 116 that is $40-63 \%$ identical to the zinc finger (DNA binding) domain of other members of the steroid receptor superfamily. The proposed regulatory protein for the mouse major histocompatibility class I proteins (H-2RIIBP; Hamada et al. 1989) had the greatest similarity $(62.7 \%$ identity), and the human thyroid hormone receptor $\left(\mathrm{c}\right.$-erb $\mathrm{A}_{;} \mathrm{T}_{3} \mathrm{R}_{\mathrm{\beta}}$ ) (Weinberger et al. 1986) was the second most similar $(59.7 \%$ identity) in this region. Although the zinc finger domain of HNF-4 is flanked by regions with no similarity to any known protein, there is a large hydrophobic region in the carboxy-terminal half of the protein lamino acids $133-373$ ) that has definite similarity to the ligandbinding domain of some of the other receptors $(20-37 \%$ identity). Again, HNF-4 is most similar to H-2RIIBP (37.3\% identity). H-2RIIBP is homologous to the human receptor $(\mathrm{RXR} \beta$ ) that binds vitamin A metabolites (Mangelsdorf et al. 1990), raising the possibility that HNF-4 binds a ligand, possibily a retinoid. This possibility is of particular interest since HNF-4 appears to have a role in regulating TTR, a protein involved in retinoid transport.

The HNF-4 protein has two other distinctive features: a proline-rich region $(23 \%)$ at the carboxyl terminus (amino acids 400-447), which could be an activator do- 
Figure 2. Nucleotide sequence of HNF-4 cDNA and deduced amino acid sequence of HNF-4 protein. (A) Schematic representation of the largest HNF-4 clone, pf7. The positions of the peptides obtained from $\mathrm{CNBr}$ cleavage of the purified protein (peptides 1-5, solid lines) and the corresponding oligonucleotide primers that yielded products in PCR (arrows, not drawn to scale) are shown. The ORF starting from the second in-frame methionine (see text) is delineated by the box. Numbers are the nucleotide positions from the beginning of the cDNA. The hatched area denotes the region used to probe a rat liver cDNA library for a fulllength clone. Zinc finger refers to the region of similarity to the DNA-binding domain of the steroid hormone receptors. $|B|$ Partial nucleotide sequence and deduced amino acid sequence of HNF-4 cDNA from rat. Sequence was obtained from the PCR products, pf7, and other cDNA isolates by the dideoxy method (Sanger et al. 1977). All regions were sequenced from at least two sources and were verified in the pf7 clone. The indicated amino acid sequences correspond to peptides $1-5 ;+1$ marks the probable initiator methionine; the bracket marks the knuckle of the first zinc finger; the asterisk $\left({ }^{*}\right)$ denotes the novel aspartic acid residue (see text). The sequence has been submitted to GenBank.

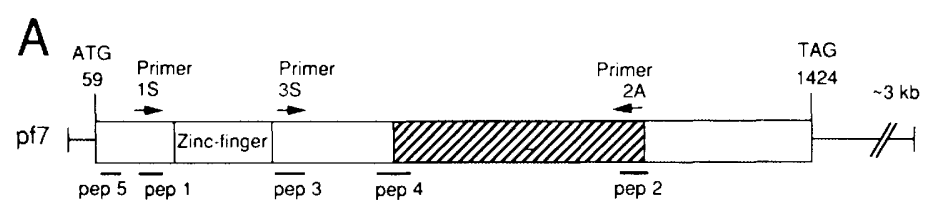

B

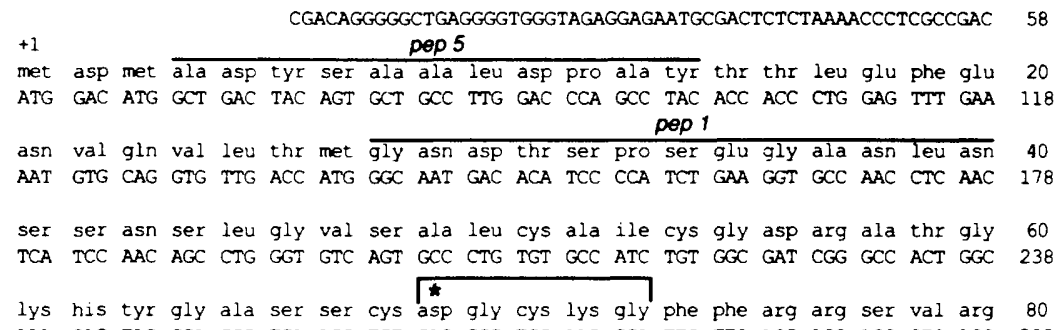
AAA CAC TAC GGA GCC TCA AGC TGT GAC GGC TGC AAG GGA TTC TTC AGG AGG AGC GTG AGG 298

lys asn his met tyr ser cys arg phe ser arg gln cys val val asp lys asp lys arg 100 AAG AAC CAC ATG TAC TCC TGA AGG TTT AGC AGG CAG TGC GTG GTA GAC AAA GAT AAG AGG 358

asn gin cys arg tyx cys arg leu lys lys cys phe arg ala giy met lys lys $\overline{\text { glu ala }} 120$ AAC CAG TGT CGT TAC TGC AGG CTC AAG AAG TGC TTC CGG GCT GGC ATG AAG AAA GAA GCC 418 pep 3

val gln asn glu arg asp arg ile ser thr arg arg ser ser tyr glu asp ser ser leu 140 GTC CAA AAT GAG CGG GAT CGG ATC AGC ACG CGG AGG TCA AGC TAC GAG GAC AGC AGC CTA 478

pro ser ile asn aia leu leu gln ala glu val leu ser gln gln ile thr ser pro ile 160 CCC TCC ATT AAT GCG CTC CTG CAG GCA GAG GTC CTG TCT CAG CAG ATC ACC TCC CCC ATC 538

ser gly ile asn gly asf ile arg ala lys arg ile aia ser ile thr asp val cys glu 180 TCT GGG ATC AAT GG GA: ATT CGG GCC AAG AGG ATT GCC AGC ATC ACG GAT GTG TGT GAG 598 pep 4

ser met lys giu gir leu leu vai leu val glu trp ala lys tyr ile pro ala phe cys 200 TCT ATG AAG GAG CAG CTG CTG GTT CTG GTC GAA TGG GCC AAG TAC ATC CCG GCC TTC TGT 658

glu leu leu leu asp asp gin val ala leu leu arg ala his ala gly glu his leu leu 220 GAA CTT CTT CTG GAT GA: CAG GTG GCG CTG CTC AGA GCC CAC GCT GGT GAG CAC CTG CTG 718

leu gly aia thr lys arg ser met val phe lys asp val leu leu leu gly asn asp tyr 240 CTT GGA GCC ACC AAG AGG TCC ATG GTG TTC AAG GAT GTG CTG CTC CTA GGC AAT GAC TAC 778

ile vai pro arg his cys pro glu leu ala glu met ser arg val ser ile arg ile leu 260 ATC GTC CCT CGG CAC TGT CCA GAG CTA GCA GAG ATG AGC CGT GTG TCC ATT CGC ATC CTC 838 asp giv leu val leu pro phe gin giu leu gin ile asp asp asn glu tyr ala cys leu 280 GAT GAG CTG GTC TIG CCO TTC CAA GAG CTG CAG ATC GAT GAT AAT GAA TAC GCC TGC CTC 898

lys ala ile ile phe phe asp pro asp aia lys giy leu ser asp pro gly lys ile lys 300 AAA GCC ATC ATC TTO TIT GAC CCA GAT GCC AAG GGG CTG AGT GAC CCA GGC AAG ATC AAG 958

arg leu arg ser gin va: gin val ser leu giu asp tyr ile asn asp arg gln tyr asp 320 CGG CTG CGG TCA CAG GTS CAG GTG AGC CTG GAG GAT TAC ATC AAC GAC CGG CAG TAT GAC 1018 ser arg gly arg phe giy glu lev leu leu leu leu pro thr leu gln ser ile thr trp 340 TCT CGG GGT CGT TTT GGA GAG CTG CTG CTG CTC CTG CCC ACT CTG CAG AGC ATT ACC TGG 1078 pep 2

glr. met ile gili gln ile gln phe ile iys leu phe gly met ala lys ile asp asn leu 360 CAG ATG ATC GAG CAG ATC CAG TTC ATC AAG CTC TTT GGC ATG GCC AAG ATT GAC AAC CTG 1138

leu gin giu met leu leu gly gly ser ala ser asp ala pro his ala his his pro leu 380 CTG CAG GAG ATG CTG CTT GGA GGG TCT GCC AGT GAC GCG CCC CAC GCC CAC CAC CCC CTG 1198

his pro his leu met gir. glu his met gly thr asn val ile val ala asn thr met pro 400 CAC CCT CAC CTG ATC CAA GAA CAC ATG GGC ACC AAT GTC ATA GTT GCC AAC ACG ATG CCC 1258 ser his leu ser asr. giy gln met ser thr pro glu thr pro gin pro ser pro pro ser 420 ICT CAC CTC AGC AAT GGA CAG ATG TCC ACC CCT GAG ACT CCA CAG CCA TCA CCA CCA AGT 1318

gly ser gly ser glu ser tyr lys leu leu pro gly ala ile thr thr ile val lys pro 440 GGC TCT GGA TCT GAA TCC TAC AAG CTC CTG CCA GGA GCC ATC ACC ACC ATC GTC AAG CCT 1378

pro ser ala ile pro gin pro thr ile thr lys gln glu ala ile aM 455 CCC TCT GCC ATC CCC CAG CCA ACG ATC ACC AAG CAG GAA GCC ATC TAGCAAGCCGCCGGGGGGT 1442 GGGGGTGAGGCTTCTGCTGGCTCACACCCTCAGAGAGCGCCTGGGTGTAACTTAGTCACGGCAAAGAGGATGTGACAAGA 1522 GGGACCAGTCCCAGAGCAGCCACTGAAAGGGCTTGTAGGCCCAAAAACATGCGCTGAGGATCGCATGCATTGCCACCCCT 1602 GACCCCACATCCGGAGGGCAGGGCTTTGCCTTGAGGAGACCCCGGCGGGGGGATGTCTTCCGCTGCCTGGACTCTTCTCA 1682 AGTTGAAGCTGCCGTCTTCATCTTCCCCTCATATCTTCCCTCAACTTCTTCACCCCTAAAGGACAACCATCTGCAG 1758 


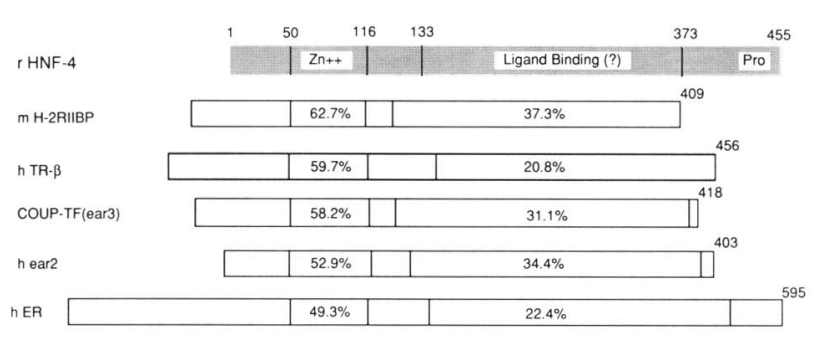

Figure 3. Structural and sequence similarity between HNF-4 protein and steroid hormone receptors. The primary amino acid sequences of rat HNF-4 (rHNF-4) were compared to members of the receptor superfamily using the FASTA program (Pearson and Lipman 1988). Pecentages denote amino acid identity within the zinc finger $\left(\mathrm{Zn}^{2+}\right)$ and ligand-binding domains. (Pro) A proline-rich domain. (m H-2RIIBP) A mouse major histocompatibility class I regulatory protein (Hamada et al. 1989) and the murine homolog of the human RXR $\beta$ receptor (Mangelsdorf et al. 1990); (h TR- $\beta$ ) the human thyroid hormone receptor $\mathrm{T}_{3} \mathrm{R} \beta$ (Weinberger et al. 1986); (h ER) the human estrogen receptor [Green et al. 1986); [COUP-TF(ear3)] the chicken ovalbumin upstream promoter transcription factor (Wang et al. 1989); (h ear2) a human v-erbA-related gene (Miyajima et al. 1988).

main (Mermod et al. 1989), and three serine/threoninerich regions $(30-38 \%)$ scattered throughout the molecule (amino acids 15-44, 129-161, and 398-426), which could be sites for phosphorylation (Krebs et al. 1988). However, whether HNF-4 is modified in any way remains to be determined.

\section{In vitro expression of $H N F-4$ cDNA}

To verify that the cDNA clone pf7 encoded the HNF-4binding protein, T7 RNA polymerase transcripts were produced and translated in vitro, and the resulting protein was tested in the mobility-shift assay. The protein synthesized in vitro bound the APF1 oligonucleotide in a sequence-specific manner (Fig. 4B, lanes 3 and 4), with the shifted complex migrating at a position identical to that of the complex formed with the material purified from rat liver (Fig. 4B, cf. lane 3 with lane 1). The position of the stop codon was confirmed by cutting the pf7 cDNA at unique restriction sites either before (PflMI, nucleotide 1309) or after (SphI, nucleotide 1584) the proposed stop codon (nucleotide 1424; Fig. 4A) and then synthesizing the protein in vitro and performing a mobility-shift assay. Figure 4, B and C, shows that translation of the SphI-cut template yielded a protein identical to that of the full-length template and that this protein produced the same gel shift band as the full-length protein. Translation of the PfIMI-cut template produced a smaller protein that formed a faster migrating shift band. These results are consistent with the fact that the stop codon is in between the SphI and PflMI sites. Plasmid template cut with $\mathrm{HgaI}$ (at nucleotide 1171) produced an even shorter protein product (by 45 amino acids, 5175 daltons) (Fig. 4C, lane 4), which gave rise to a faster migrating shift complex (Fig. 4B, lane 9). When the truncated in vitro translation products were tested for DNA binding to the oligonucleotide containing the
HNF-4 site from the TTR gene, HNF4P, identical results were obtained (gel not shown). The results of the in vitro translation experiments confirm that the pf 7 cDNA encodes a protein that binds to the HNF-4 recognition site in a fashion analogous to that of the purified protein.

\section{HNF-4 binds to its recognition site as a dimer}

Further examination of translation products produced from truncated cDNA templates showed that a polypeptide containing amino acids 1-219 (HphI-cut, Fig. 4C, lane 5) did not bind DNA even though the entire zinc finger region, the DNA binding domain of the steroid receptors, was present (Fig. 4A; Fig. 4B, lane 11). This suggested that the region between amino acids 219 and 374 , the possible ligand-binding domain, might be required for binding of the HNF-4 protein to its recognition site. Since amino acids in the ligand-binding domain of the estrogen receptor are known to be necessary for receptor dimerization and subsequent DNA binding (Kumar and Chambon 1988; Fawell et al. 1990), we determined whether HNF-4 binds to its recognition site as a monomer or as a dimer. The full-length cDNA (XhoI) was cotranslated in vitro with either of the two truncated products that bind DNA (PflMI and HgaI), and the products were tested in the mobility-shift assay. When the full-length and truncated transcripts were translated together, complexes of intermediate mobility were produced with both the APFl probe (Fig. 4D, lanes 3 and 5) and the TTR probe -151 to -130 (not shown). These intermediate bands were most likely produced by heterodimers between the full-length and truncated proteins, which suggests that the shift complex we have been monitoring consists of a homodimeric protein bound to the probe. Since no shift complexes corresponding to monomers were detected with either the in vitro-translated or the purified protein and since the transcript lacking the proposed dimerization domain (HphI) did not bind the probe at all, we conclude that protein dimerization is required for HNF-4 to bind to its recognition site.

\section{Transcriptional activation by cloned HNF-4}

Since deletion of the HNF-4-binding site in the TTR promoter severely reduced transcription of transfected templates (Costa et al. 1989), we determined whether HNF-4 produced from the cloned cDNA would activate transcription of a target gene. An expression vector containing HNF-4 cDNA was cotransfected into HeLa cells with constructs containing a reporter gene, chloramphenicol acetyltransferase (CAT), which either did or did not contain two copies of the HNF-4 recognition site from the apoCIII gene (APF1-HIV-CAT and HIVCAT, respectively). The results are shown in Figure 5. The HNF-4 expression vector containing the cDNA in the sense orientation stimulated CAT production from the reporter constructs only when the HNF-4 sites were present (Fig. 5, cf. lanes 2-4 with lanes 6-8). The vector containing the cDNA in the antisense orientation, on 


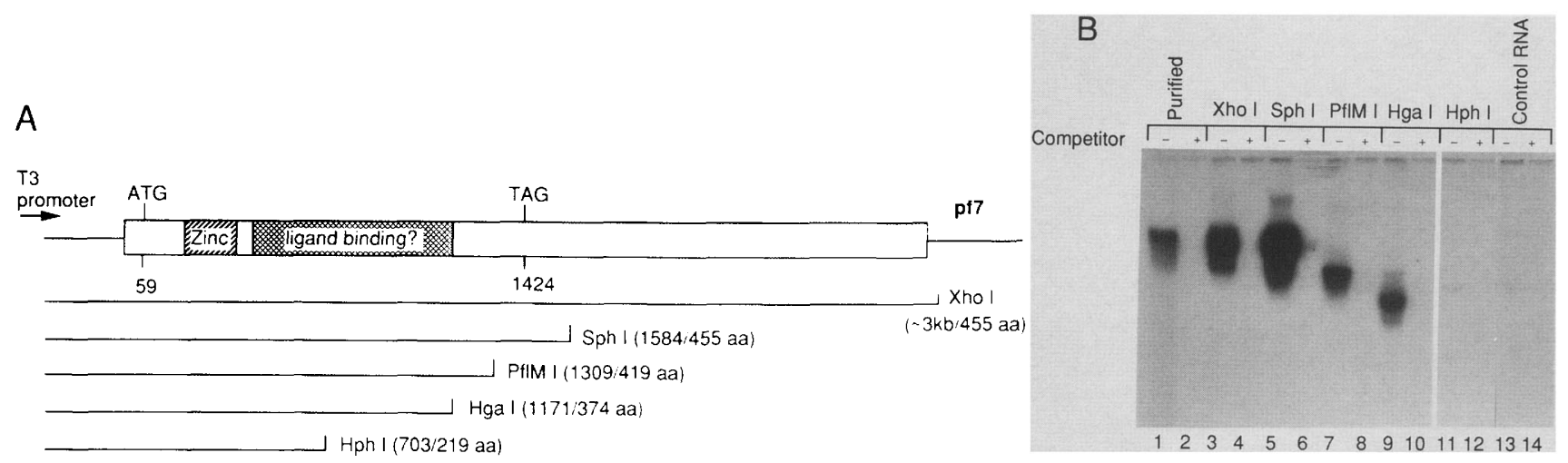

Figure 4. In vitro-synthesized HNF-4 protein binds to its recognition site as a dimer. $(A)$ Schematic representation of truncated forms of HNF-4 protein synthesized in vitro. pf7 DNA [in Bluescript $\mathrm{SK} \mid-\|$ was cut with the restriction enzymes indicated and transcribed in vitro with T3 RNA polymerase. The resulting mRNAs were translated with rabbit reticulate lysate (Promega) in the presence of $\left[{ }^{3} \mathrm{H}\right]$ leucine. The open box represents the $3-\mathrm{kb}$ cDNA insert in pf7; the numbers are the nucleotide positions of the start (ATG) and stop (TAG). The position of the cut site of the restriction enzymes and the length of the polypeptide in amino acids (aa) resulting from translation beginning at nucleotide 59 are given. $(B)$ Mobility-shift assay of in vitro-synthesized HNF-4 products. Reactions contained $0.5 \mathrm{ng}{ }^{32} \mathrm{P}$-labeled APF 1 probe and 2 $\mu \mathrm{g}$ poly $[\mathrm{d}(\mathrm{I}-\mathrm{C})]$ in the presence of $25 \mathrm{ng}$ unlabeled nonspecific $(-)$ $(-175$ as in Fig. $1 B)$ or specific $(+)$ oligonucleotide (APF 1$)$ as competitor. (Lanes 1 and 2) Purified HNF-4 (fxn 38); (lanes 3-12) in vitro-translation reactions $(2 \mu \mathrm{l})$ as described in $A$; (lanes 13 and

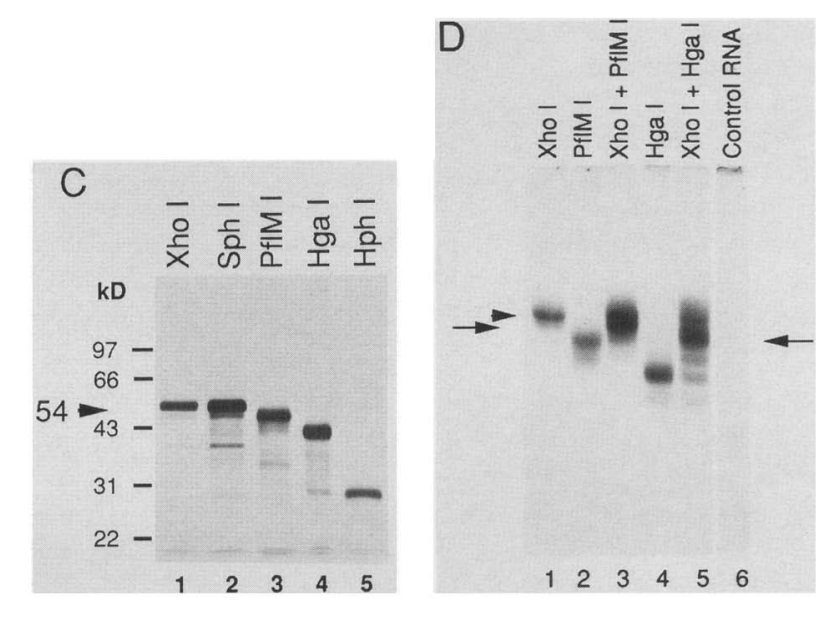
14) bovine mosaic virus (BMV) RNA added to the in vitro-translation system as a negative control. (C) SDS-PAGE of in vitro-synthesized HNF-4 products. Autoradiogram of a $10 \%$ gel (treated with En ${ }^{3}$ hance, NEN) containing $1 \mu l$ of translation reactions described in $A$. The positions of Coomassie-stained markers are shown at left. $(D)$ Mobility-shift assay showing dimer formation. pf 7 DNA cut with the restriction enzymes indicated was transcribed as in $A$. The resulting RNAs were mixed as noted and translated in vitro. The translation reactions were assayed as in $B$ in the presence of nonspecific competitor. Arrows indicate the complexes formed by heterodimeric protein; the arrowhead marks the shift complex normally seen, presumably, a homodimer.

the other hand, did not activate CAT expression significantly above background (Fig. 5, cf. lanes 9-11 with lane 1). Thus, we conclude that under the conditions of these experiments, HNF-4 protein can activate transcription of a target gene. Furthermore, since the cells in which the activation occurred were nonhepatic in origin, no liver-specific post-translational modifications seem to be necessary for HNF-4 function.

\section{Tissue distribution of HNF-4 mRNA is limited}

HNF-4-binding activity was first found in liver. Since then, it has also been found in kidney and intestine but not in spleen or brain (Costa et al. 1990). To see whether the tissue distribution of the HNF-4-binding activity reflected that of HNF-4 mRNA and to determine the size of the HNF-4 mRNA, a Northern blot analysis was performed. As shown in Figure 6, the HNF-4 mRNA is present as a single species in rat liver, kidney, and intestine but is absent in spleen, brain, white fat, lung, and heart. This result supports the conclusion that HNF-4 is neither present exclusively in liver nor present in all tissues and is consistent with the fact that apoCIII is expressed in the intestine as well as the liver (Breslow
1988|. The size of the mRNA was the same, $\sim 4.5 \mathrm{~kb}$, in all rat tissues as well as in mouse liver (Fig. 6, lane 1). This is consistent with the fact that the pf7 clone isolated from the rat liver cDNA library contains a cDNA insert $\sim 3 \mathrm{~kb}$ long but does not contain a polyadenylation site. A weak signal at $\sim 2.3 \mathrm{~kb}$ was also seen (Fig. 6 , lanes 2 and 3 , which varied in amount between blots. Its relation to the major signal, if any, is not known.

\section{HNF-4 binds to an LF-A1 site}

LF-Al is a liver-enriched factor that binds to a site required for transcription of human $\alpha 1-\mathrm{AT}$ (Monaci et al. 1988; HNF-2 in Li et al. 1988), apolipoprotein Al, and 3 ther genes expressed in hepatocytes (Hardon et al. 1988; Vaulont et al. 1989). Since the LF-Al sites are similar in sequence to the HNF-4 binding sites (Table 1), we used the mobility-shift assay to test the affinity of the HNF-4 protein for the LF-Al site from the $\alpha 1$-AT gene (Table 1). HNF-4 protein, either purified from rat liver or translated in vitro from the HNF-4 cDNA, bound the LF-Al probe very well, producing a shift complex indistinguishable from those formed with the APF1 and HNF4P probes (Fig. $7 A_{\text {; }}$ cf. lanes 3 and 9 with lanes 1 and 


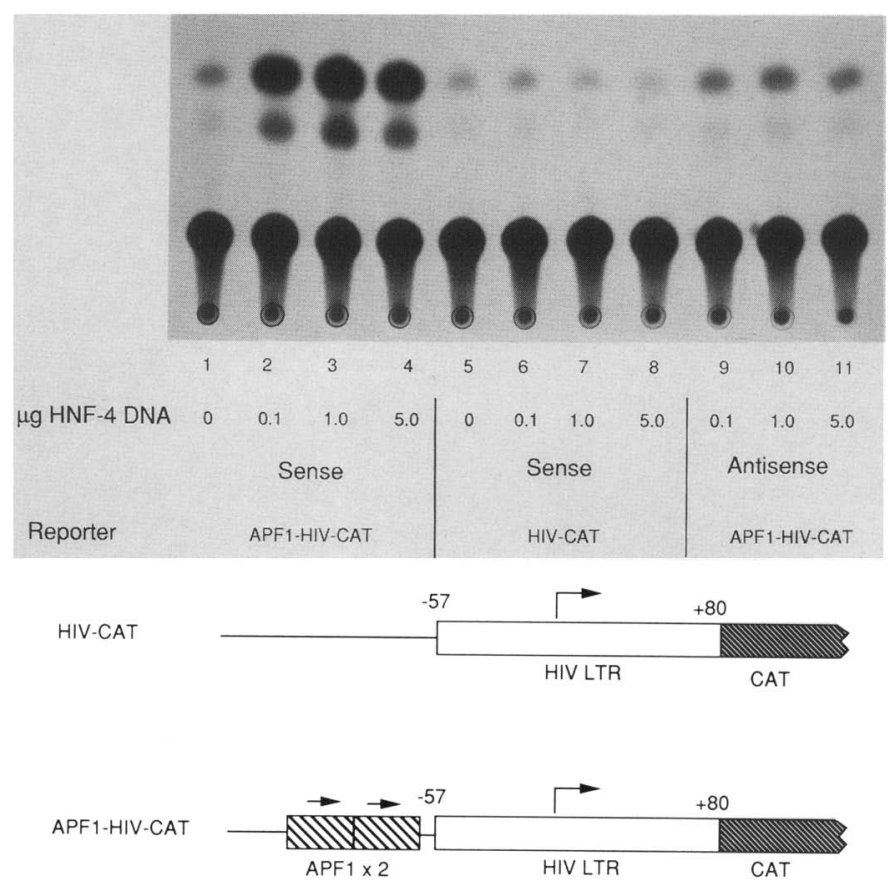

Figure 5. Transcriptional activation by HNF-4 cDNA. (Top) Autoradiogram of CAT assay; (bottom) schematic representation of reporter constructs. Expression vector DNA $(0-5.0 \mu \mathrm{g})$ containing HNF-4 cDNA (the 3-kb insert of pf7) in either the sense or antisense direction was cotransfected into HeLa cells with a CAT reporter construct $(2 \mu \mathrm{g})$, either lacking (HIV-CAT) or containing HNF-4 recognition sites (APF1-HIV-CAT). The HIV LTR served as the basal promoter element. Densitometry of the autoradiogram indicated a 10- to 15-fold induction by HNF-4 cDNA (cf. lanes 2-4 with lanes 9-11).

5 and lanes 7 and 11 , respectively|. In fact, the LF-Al probe gave a stronger signal than the HNF4P probe (all probes were labeled to the same specific activity in Fig. 7A). To see whether the major protein species that binds the LF-Al site in crude extracts is the same as that which binds the probe used to purify HNF-4 protein, the mobility-shift assay was carried out with crude rat liver nuclear extracts. The results show that two major shift complexes were formed with the LF-A1 probe, both of which were specifically competed by the LF-Al, APFl, and HNF4P oligonucleotides and one of which migrated at a position identical to that of the major complex formed with the APF1 probe (Fig. 7B, lanes 1 and 6-9). To identify the proteins binding to the LF-Al probe, the shift reaction was incubated with antiserum raised to a synthetic peptide derived from the carboxyl terminus of the HNF-4 protein. This antiserum not only retarded the mobility of the major shift complex formed with the APFl probe but it also retarded both DNA-protein complexes formed with the LF-Al probe (Fig. 7B, lanes 5 and 10$)$. This finding suggests that the major protein species binding to the LF-Al probe in rat liver nuclei is either identical to HNF-4 or at the very least contains a region that is nearly identical to the epitope against which the antiserum reacts. Similar results were seen with mouse liver nuclear extracts (gel not shown).

When the shift reaction with the HNF4P probe and crude liver extracts was incubated with the antiserum, the result was the same as with the APF1 probe: Only a part of the total shift complex was affected (Fig. 7B, lane 15). Therefore, unlike the LF-Al probe, both the APF1 and the HNF4P probes produced shift complexes that were specifically competed by unlabeled oligonucleotides containing HNF-4 sites but that were not affected by incubation with the HNF-4 antiserum. Since all of the shift complexes formed with the purified HNF-4

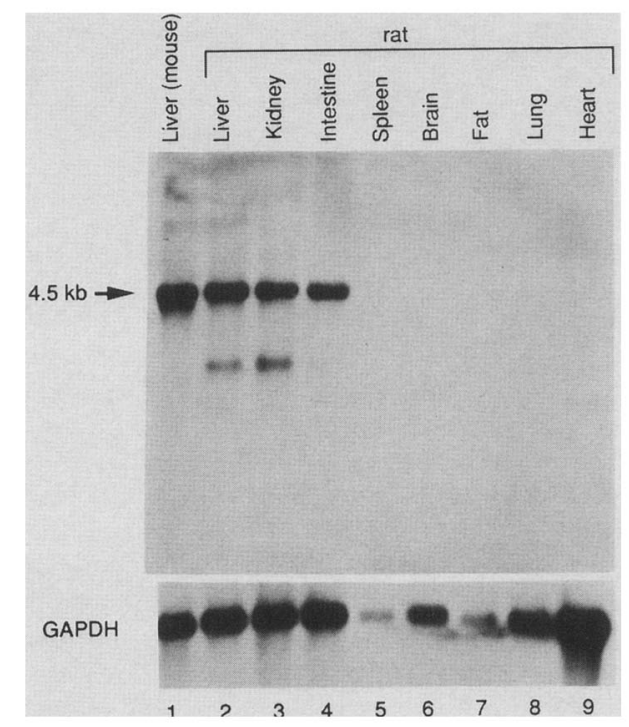

Figure 6. Limited tissue distribution of HNF-4 mRNA. Northern blot analysis of poly $(\mathrm{A})^{+}$RNA from different rat and mouse tissues using an HNF-4 cDNA fragment as probe (top). A glyceraldehyde 3-phosphate dehydrogenase (GAPDH) probe served as a control (bottom). 
protein and either the APF1 probe (Fig. 7B, lane 16 and 17) or the HNF4P probe (gel not shown) reacted with the antiserum, it seems likely that there are other proteins unrelated to HNF-4 in the crude liver extract that recognize the same oligonucleotides as does HNF-4. However, it is possible that the shift complexes that did not react with the antiserum simply correspond to a form of the HNF-4 protein that lacks the carboxy-terminal amino acids and, therefore, the immunogenic epitope.

\section{Discussion}

In this report we describe the protein purification, cloning, and sequencing of a new tissue-restricted mam-

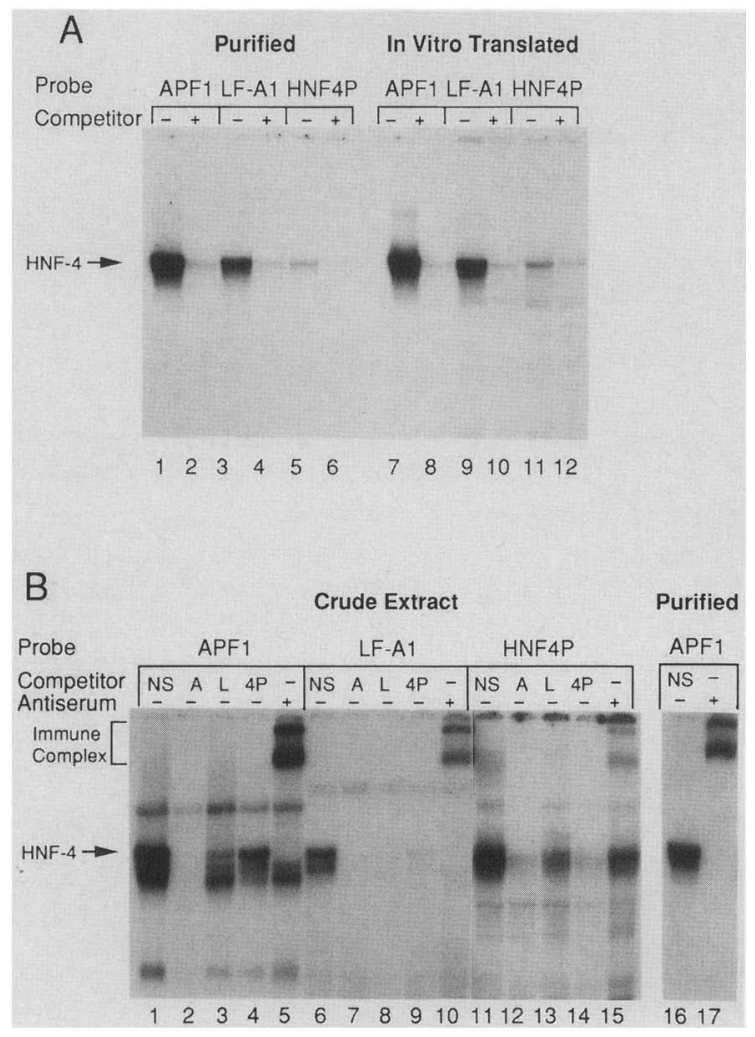

Figure 7. HNF-4 binds to an LF-Al site. (A) Mobility-shift assay with either purified (Mono $\mathrm{Q}, \mathrm{fxn} 38,0.03 \mu \mathrm{l}$ ) or in vitrotranslated HNF-4 (SphI; Fig. 5, $2 \mu \mathrm{l}$ ) and one of three ${ }^{32} \mathrm{P}$-labeled probes (APFl, LF-Al, HNF4P, $0.5 \mathrm{ng}$ ), as indicated. Reactions contained $2 \mu \mathrm{g}$ poly[d(I-C)] and $25 \mathrm{ng}$ of unlabeled oligonucleotide, either nonspecific $(-)(-175$ as in Fig. 1B) or specific $(+)$ oligonucleotide (APFl, LF-Al, or HNF4P) as competitor. $(B)$ Mobility shift assay with either crude rat liver nuclear extract $(2.5 \mu \mathrm{g})$ or purified HNF-4 protein as in $A$. All reactions contained $2 \mu \mathrm{g}$ poly[d(I-C)] and $50 \mathrm{ng}$ of unlabeled nonspecific (NS) oligonucleotide $(-175$ as in Fig. $1 \mathrm{~B})$. Specific competitions also contained $50 \mathrm{ng}$ unlabeled oligonucleotide: (A) APF 1; (L) LF-A I; (4P) HNF4P as in Table 1. Antiserum to the carboxyl terminus of HNF-4 was added as described in Materials and methods. The immune complex is antibody plus protein bound to probe; preimmune serum did not retard the mobility of the shift complexes (not shown). The arrow marks the position of the shift complex formed with HNF-4 protein. The section with the HNF4P probe was exposed 6.75 times longer than the section with the APF1 and LF-A1 probes. malian transcription factor that we have termed HNF-4. HNF-4 was so named because its presence was first detected in liver extracts but not in extracts from several other tissues, and its recognition site was distinct from that of three previously described proteins found mainly in the liver (Costa et al. 1989).

\section{HNF-4-a novel member of the steroid hormone receptor superfamily}

The deduced amino acid sequence of the HNF-4 protein indicates that it is a member of the steroid/thyroid hormone receptor superfamily, an ever-increasing group of ligand-dependent transcription factors that possess a high degree of similarity in their DNA-binding (zinc finger) domains. While HNF-4 is similar in sequence to the other factors in the zinc-finger domain, it could be a member of a new subfamily. The members of the superfamily have been classified according to the amino acid sequence in the knuckle of the first zinc finger (between $\mathrm{C}_{3}$ and $\mathrm{C}_{4}$, referred to as the $\mathrm{P}$ box |, a region important in recognizing the sequence of the half-site of the palindrome in HREs (Danielson et al. 1989; Mader et al. 1989; Umesono and Evans 1989; for review, see Forman and Samuels 1990). For example, members of the thyroid hormone receptor (TR) subfamily contain amino acids EGCKG and bind a thyroid response element (TRE), while members of the estrogen receptor (ER) subfamily contain amino acids EGCKA and bind an estrogen response element (ERE). The sequence of HNF-4 in this region (DGCKG) is most similar to that of the TR subfamily except that it contains an aspartic acid (D) in place of a glutamic acid (E) following $\mathrm{C}_{3}$. HNF-4, however, does not bind a TRE (nor an ERE significantly), even though the TRE is almost identical ( 9 of 12 residues) to the HNF-4 consensus site given in Table 1 (TRE = AGCTCTCAGGTCATGACCTGA; F.M. Sladek, unpubl.). Although HNF-4 is the only factor described to date with the DGCKG sequence, considering the sizes of the other subfamilies, we anticipate that more will be found in the future (see receptors compiled in Umesono and Evans 1989; Forman and Samuels 1990-also, hap/ RAR $\beta$ in de The et al. 1987 and Brand et al. 1988; H-2RIIBP in Hamada et al. 1989; and N10 in Ryseck et al. 1989).

Like the well-characterized receptor proteins /estrogen in Kumar and Chambon 1988 and Fawell et al. 1990; thyroid hormone and retinoic acid in Forman et al. 1989; and glucocorticoid, in Tsai et al. 1988), HNF-4 protein binds to its recognition site as a homodimer (Fig. 4D), even though that site lacks obvious dyad symmetry. Receptor dimerization in the other receptors has been localized to a series of heptad repeats of hydrophobic residues in the ligand-binding domain (Forman et al. 1989; Fawell et al. 1990; Forman and Samuels 1990). The corresponding region in HNF-4 is also required for DNA binding (Fig. 4B) and contains at least 12 heptad repeats. The existence of homodimer interaction raises the possibility of heterodimer formation between HNF-4 and other transcription factors, as has been seen between the 
thyroid hormone and retinoic acid receptors (Forman et al. 1989; Glass et al. 1989).

Since TTR expression is not dependent on hormone regulation, we did not anticipate that HNF-4 would fall into this ligand-dependent superfamily. However, its membership in this family, and its limited homology to the ligand-binding domains of other receptors with known ligands, raises the possibility that HNF-4 has an as yet unidentified ligand. Considering the number and variety of genes that HNF-4 controls (discussed below), the possibility of a ligand for HNF-4 is of considerable interest. Nonetheless, since so many other members of the superfamily fall into this category of "orphan receptors" - proteins for which no ligand has been identified (e.g., COUP-TF in Wang et al. 1989; ear2 in Miyajima et al. 1988; ERR in Giguere et al. 1988; and N10 in Ryseck et al. 1989|, it is possibile that these receptors have no ligands. Since the ligand-binding domain overlaps with the dimerization domain, amino acid conservation in this region could be for the purpose of dimerization and not for the purpose of binding a ligand.

\section{HNF-4 and other factors}

LF-A1 was originally identified in the $\alpha 1$-AT gene promoter (Li et al. 1988; Monaci et al. 1988) as a site conferring positive transcription regulation in vivo and in vitro. LF-A1 sites have been found also in the regulatory regions of the apolipoprotein Al gene, haptoglobin-related genes (Hardon et al. 1988), and the pyruvate kinase L-type gene (Vaulont et al. 1989). In this paper we present DNA-binding data indicating that HNF-4 protein has a high affinity for an LF-Al recognition site; and based on antiserum reactivity, we suggest that HNF-4 could be identical to LF-A1. However, it is always possible that there are other proteins in rat liver nuclei that are distinct from HNF-4 but that bind specifically to the LF-A1 site. For example, our data cannot rule out the possibility that a protein exists that binds specifically to the LF-Al site and cross-reacts with the HNF-4 antiserum but that is distinct from the factor we have cloned.

Although it is ambiguous as to whether there exists more than one protein that binds the LF-Al site, it seems certain that there are proteins in addition to HNF-4 that bind the APF1 site from the apoCIII gene and the HNF4P site from the TTR gene. It is not known what other factors might bind the TTR site, but it is known that there are at least two proteins that are distinct from HNF-4 but that bind to the apoCIII site with high affinity. One is apolipoprotein regulatory protein 1 (Arpl), which is also a steroid receptor superfamily member but negatively regulates the apoCIII site (S. Karanthanasis, pers. comm.). The other is the previously described apolipoprotein factor 1 (AF-1), which regulates the human apoCIII and apoBl00 genes (Reue et al. 1988; Leff et al. 1989) but does not react with HNF-4 antiserum (T. Leff and F.M. Sladek, unpubl.). Since overexpression of apoCIII in vivo has been linked to hypertriglyceridemia, a condition related to heart disease and obesity (Ito et al. 1990), it is of particular interest to see how HNF-4 interacts with these other factors to control the rate of transcription of the apoCIII gene. The phenomenom of more than one transcription factor binding to a given DNA element in the promoter region of a gene is not an uncommon one [for review, see Wingender (1990); for hormone receptors, see also von der Ahe et al. (1985), Umesono et al. (1988), and Schule et al. (1990); for liver-enriched factors, see Lai et al. (1990) and Mueller et al. (1990)].

\section{HNF-4 and liver-specific gene expression}

As noted in the introductory section, a major goal of our work on proteins that control liver-specific gene expression is to identify transcription factors that are themselves transcriptionally controlled in the liver. HNF-4 appears to be such a factor: HNF-4 can activate transcription in cells that are not of hepatic origin (Fig. 5), indicating that no liver-specific modifications are required for HNF-4 function, and HNF-4 mRNA is absent in many tissues (Fig. 6). These results, taken together with the demonstration that the rate of HNF-4 gene transcription is high in liver but insignificant in a number of other tissues (K.G. Xanthopoulos, V.R. Prezioso, W.S. Chen, F.M. Sladek, R. Cortese, and J.E. Darnell, in prep.), indicate that HNF-4, like HNF-3 (Lai et al. 1990) and C/EBP (Xanthopoulos et al. 1989), is a transcriptionally controlled transcription factor. Antecedent regulatory genes in a regulatory cascade can now be sought with confidence by studying the factors that regulate the genes encoding these regulatory proteins.

When we began investigating tissue-specific expression, two simple hypotheses were entertained that now seem to be ruled out. First, there is no universal liverspecific transcription factor or group of transcription factors: HNF-1, C/EBP, HNF-3, and HNF-4 all have binding sites on several genes, but none is a "master" positive-acting factor. Indeed, all of these factors are present in tissues other than liver and some are even present in tissues of different embryonic origin as the liver [e.g., HNF-1, also in kidney and spleen (Baumhueter et al. 1990); C/EBP, also in brain, fat, intestine, lung, and skin (Birkenmeier et al. 1989; Xanthopoulos et al. 1989; Kuo et al. 1990; Ruppert et al. 1990); HNF-3A, intestine in small amounts (Lai et al. 1990); HNF-4, kidney, and intestine (Fig. 6)]. In addition to varying in their tissue distribution, these factors have protein structures that classify them as members of four distinct groups of regulators, none of which is found exclusively in the liver (HNF-1, homeo domain; C/EBP, leucine zipper; HNF-3, unclassified; HNF-4, steroid hormone receptors|. Second, we cannot immediately understand the logic that unites the group of genes that a particular factor may help regulate. For example, HNF-4 apparently acts positively on genes encoding apolipoproteins, which are involved in cholesterol homeostasis, and on TTR, which carries thyroid hormone and vitamin A in the serum, as well as al-AT, a protease inhibitor, pyruvate kinase, which plays a role in glycolysis, and gluta- 
mine synthetase, which acts in amino acid biosynthesis (C.F. Kuo and F.M. Sladek, unpubl.). Why this factor is involved in regulating this varied assortment of genes is far from obvious.

\section{Materials and methods}

Extract preparation and chromatography were carried out at $4^{\circ} \mathrm{C}$.

\section{Preparation of rat liver nuclear extract}

Crude rat liver nuclear extracts were prepared using the method of Gorski et al. (1986), modified as follows: $\sim 50$ grams of tissue was removed from three to four freshly killed male rats (Sprague-Dawley, $\sim 20$ weeks old), homogenized in $30 \mathrm{ml}$ of buffer A [10 mM HEPES at pH 7.9, $25 \mathrm{~mm} \mathrm{KCl}, 0.15 \mathrm{~mm}$ spermine, $0.5 \mathrm{~mm}$ spermidine, $1.0 \mathrm{~mm}$ EGTA, $1.0 \mathrm{~mm}$ EDTA, $1 \mathrm{~mm}$ dithiothreitol (DTT), $0.32 \mathrm{M}$ sucrose), dounced five to seven times (pestle A), and diluted with two volumes of buffer B (as A, except $2 \mathrm{M}$ sucrose). Twenty-seven milliliters of the homogenate was layered on a $10-\mathrm{ml}$ cushion of buffer $B$ and centrifuged in a Beckman SW27 rotor at $15 \mathrm{rpm}$ for $45 \mathrm{~min}$. The pelleted nuclei were rinsed once in buffer C (as buffer A, except $20 \%$ glycerol in place of sucrose), dounced five times (pestle $B$ |, and brought to $0.41 \mathrm{M} \mathrm{KCl}$ with buffer $\mathrm{D}$ (as C, except $1 \mathrm{M} \mathrm{KCl}$ ). The protein was extracted by gentle rocking at $4^{\circ} \mathrm{C}$ for $45 \mathrm{~min}$. The chromatin was pelleted by centrifugation at $180,000 \mathrm{~g}$ for 45 $\mathrm{min}$, and the supernatant /crude nuclear extract, $3.5-5.0 \mathrm{mg} / \mathrm{ml}$ protein) was frozen immediately in liquid $\mathrm{N}_{2}$ and stored at $-80^{\circ} \mathrm{C}$. DTT and protease inhibitors (phenylmethylsulfonyl fluoride, $0.5 \mathrm{~mm}$; benzamidine $\mathrm{HCl}, 1 \mathrm{~mm}$; leupeptin, 0.5 $\mu \mathrm{g} / \mathrm{ml}$; pepstatin, $1 \mu \mathrm{g} / \mathrm{ml}$ ) were added to all buffers just prior to use.

\section{Mobility-shift assay and purification of HNF-4}

Gel mobility-shift (DNA-binding) assays (Fried and Crothers 1981) were carried out in $15-\mu$ l reactions in shift buffer $(20 \mathrm{mM}$ HEPES at $\mathrm{pH} 7.91,40 \mathrm{mM} \mathrm{KCl}, 2 \mathrm{~mm} \mathrm{MgCl} 2,1 \mathrm{~mm}$ DTT, 0.5 mM EGTA, $4 \%$ Ficoll) and contained $1-2 \mu l$ of protein extract and $0.5 \mathrm{ng}$ of double-stranded oligonucleotide probe labeled with ${ }^{32} \mathrm{P}$ by Klenow. Reactions were incubated at room temperature for $30 \mathrm{~min}$. Poly[d(I-C)], oligonucleotide competitor, and bovine serum albumin (BSA) were added as indicated. Proteinbound DNA complexes ( $5 \mu$ l of shift reaction) were separated from free probe by electrophoresis on an $8 \%$ polyacrylamide gel in $25 \mathrm{~mm}$ Tris-borate, $0.25 \mathrm{~mm}$ EDTA, at $4^{\circ} \mathrm{C}$.

Chromatography fractions were assayed by the mobility-shift assay using either the APFl or HNF4P oligonucleotide as probe. Crude nuclear extract (up to $300 \mathrm{mg}$ ) was applied to a $60-\mathrm{ml}$ heparin-agarose (Sigma, type I) column equilibrated in buffer $\mathrm{E}$ (20 mM HEPES at $\mathrm{pH} 7.9,10 \%$ glycerol, $1 \mathrm{~mm}$ DTT, $0.1 \mathrm{~mm}$ EDTA, $0.1 \mathrm{mM}$ EGTA) containing $150 \mathrm{~mm} \mathrm{KCl}$. The column was developed with a $400-\mathrm{ml}$ linear gradient from 0.2 to $0.8 \mathrm{M}$ $\mathrm{KCl}$. Fractions with HNF-4 activity $(0.50-0.55 \mathrm{M} \mathrm{KCl})$ were pooled, precipitated with ammonium sulfate $(300 \mathrm{mg} / \mathrm{ml}$ final $\mid$, dissolved in buffer $\mathrm{F}$ [as buffer $\mathrm{E}$ but with $0.05 \%$ Nonidet P- 40 (NP-40)] containing $100 \mathrm{mM} \mathrm{NaCl}$, dialyzed, and loaded onto a 240-ml Sephacryl S300 (Pharmacia) column. Active fractions, eluting just after the void volume, were loaded onto a $5-\mathrm{ml}$ double-stranded DNA cellulose (Sigma) column equilibrated in buffer $\mathrm{F} / 100 \mathrm{~mm} \mathrm{NaCl}$. The column was developed with a three-step gradient: $150 \mathrm{~mm}, 300 \mathrm{~mm}$, and $1 \mathrm{M} \mathrm{NaCl}$. Active fractions (eluting at $300 \mathrm{~mm} \mathrm{NaCl}$ ) were diluted to $100 \mathrm{mM}$ $\mathrm{NaCl}$, and poly[d(I-C) and sonicated, denatured salmon sperm DNA were added to $10 \mu \mathrm{g} / \mathrm{ml}$ each. After $10 \mathrm{~min}$ on ice, the sample was loaded onto a 2-ml HNF4P oligonucleotide affinity column prepared as in Kadonaga and Tjian (1986) and equilibrated in buffer $\mathrm{F} / 100 \mathrm{~mm} \mathrm{NaCl}$. The column was developed with a $20-\mathrm{ml}$ linear gradient from 0.1 to $1.0 \mathrm{M} \mathrm{NaCl}$. Active fractions, eluting at $0.18-0.3 \mathrm{M} \mathrm{NaCl}$, were diluted to $0.1 \mathrm{M}$ $\mathrm{NaCl}$, supplemented with poly[d(I-C)] and salmon sperm DNA to $3 \mu \mathrm{g} / \mathrm{ml}$ each and passed over a 2-ml APF1 oligonucleotide affinity column as described above. The HNF-4-binding activity, eluting at $0.25-0.5 \mathrm{M} \mathrm{NaCl}$, was dialyzed against buffer $\mathrm{T}$ (as buffer $\mathrm{F}$ but with $20 \mathrm{mM}$ Tris- $\mathrm{HCl}$ at $\mathrm{pH} 8.0$ and $20 \%$ glycerol) containing $100 \mathrm{mM} \mathrm{NaCl}$ and loaded onto a FPLC Mono Q HR 5/5 (Pharmacia) column. The column was developed with a linear gradient from 0.1 to $1.0 \mathrm{M} \mathrm{NaCl}$. The peak fraction in one preparation (fraction 38) eluted at $\sim 0.42 \mathrm{M} \mathrm{NaCl}$. Purified HNF-4 refers to material passed over all five columns.

\section{Cyanogen bromide cleavage and protein sequencing}

Approximately $10 \mu \mathrm{g}$ (200 pmoles) of purified HNF-4 (fxn 38) was brought to $1.3 \mathrm{M}$ guanidine $\mathrm{HCl}$ (ultrapure, ICN) and $0.03 \%$ $\beta$-mercaptoethanol (Sigma) and loaded onto a reverse-phase HPLC column (Aquaporebutyl $30 \times 2.1 \mathrm{~mm}, 7 \mu \mathrm{m}$, Brownlee Laboratories) equilibrated in buffer $\mathrm{H}$ [5\% l-propanol in $10 \mathrm{mM}$ trifluoroacetic acid (TFA)]. The column was developed with a 9$\mathrm{ml}$ gradient from $5 \%$ to $59 \%$ 1-propanol in $10 \mathrm{mM}$ TFA at a flow rate of $0.15 \mathrm{ml} / \mathrm{min}$. Fractions containing HNF-4 $147-50 \%$ propanol/ were pooled, dried, and treated with $5 \mu \mathrm{g} / \mathrm{ml} \mathrm{CNBr}$ in $50 \%$ formic acid for $24 \mathrm{hr}$. The $\mathrm{CNBr}$-generated peptides were separated by HPLC using the conditions given above. Fractions containing peptides were either sequenced directly on an Applied Biosystems gas phase (model 470 ) sequenator (peptides 1 , 2 , and 5 ) or purified further on a $16.5 \%$ SDS-polyacrylamide gel and processed for sequencing as in Matsudaira (1987; peptides 3 and 4)

\section{Isolation of HNF-4 CDNA clones}

Oigonucleotide primers corresponding to the least degenerate regions of peptides 1,2 , and 3 were synthesized: Primer is (from sense direction of peptide 1) was $5^{\prime}-\mathrm{CC}(\mathrm{C} / \mathrm{A}$ ) tcc(C/G)AXGGNGCNAAYYTNAA-3', where $\mathrm{N}=\mathrm{A}+\mathrm{G}$ $+T+C, X=A+G, Y=C+T$. Primer lA (antisense of peptide 1) was 5'-TTAggTTNGCNCCYT/G/C)N(G/C)XNGG3'. Primer $2 S$ (sense of peptide 2) was 5'-CATCTAGAATtGAgCAgAT/Y/A)CA/G/A)TTYAT/Y/A)AA-3'. Primer 2A lantisense of peptide 2) was 5'-AACGTCAGAgcTT(X/T)AT/G/ A)AAYTG(X/T)ATYTGYTC-3'. Primer 3S (sense of peptide 3) was $5^{\prime}$-GAgGCtGTNCAXAAYGAX|C/A|GNGA-3'. Primer 3A (antisense of peptide 3) was $5^{\prime}-\mathrm{TC}(\mathrm{Y} / \mathrm{G}) \mathrm{C}(\mathrm{G} / \mathrm{T}) \mathrm{cTCXTTYTG-}$ NACNGCYTC-3'. Lowercase letters indicate codon usage according to Lathe (1985); underlined regions indicate an XhoI restriction site used for subcloning. The primers were used in the PCR (Saiki et al. 1988) in pairwise combinations (primer $1 S+2 A, 1 S+3 A$, etc.) following the protocol by Perkin-Elmer Cetus. Fifty-microliter reactions containing $0.5-4 \mu \mathrm{g}$ of each primer (1S and 1A, $4 \mu \mathrm{g}$; $2 \mathrm{~S}$ and $2 \mathrm{~A}, 0.5 \mu \mathrm{g} ; 3 \mathrm{~S}, 1 \mu \mathrm{g} ; 3 \mathrm{~A}, 1.5 \mu \mathrm{g}$ ) and $10 \mu \mathrm{l}$ of rat liver cDNA library in $\lambda$ Zap II (from Strategene, $1.5 \times 10^{6}$ independent recombinants, reamplified and used at $4 \times 10^{10} \mathrm{pfu} / \mathrm{ml}$ ) underwent 30 cycles in a DNA thermal cycler (Perkin-Elmer Cetus). Each cycle consisted of $1 \mathrm{~min}$ at $94^{\circ} \mathrm{C}, 1$ min at $57^{\circ} \mathrm{C}, 2.5 \mathrm{~min}$ (plus $5 \mathrm{sec} / \mathrm{cycle}$ ) at $72^{\circ} \mathrm{C}$. PCR products were cloned into the polylinker region of Bluescript $\mathrm{KS} \mid+1$ (Stratagene) and sequenced using the Sequenase kit from U.S. Biochemicals. dITP reactions were performed on regions where the sequence was ambiguous. 
The singly amplified rat liver cDNA library (Stratagene) was screened for full-length clones as described in Maniatis et al. (1982), except the nitrocellulose filters were autoclaved to bind the DNA, no formamide was used in the prehybridization buffer, and hybridization and washings were done at $50^{\circ} \mathrm{C}$. The probe was the subcloned PCR product obtained with primers $3 \mathrm{~S}$ and $2 \mathrm{~A}$ labeled with ${ }^{32} \mathrm{P}$ by random priming (Feinberg and Vogelstein 1983).

\section{Trans-activation assay}

The HIV-CAT reporter construct $(-5 \mathrm{~kb})$ contained -57 to +80 of the human immunodeficiency virus long terminal repeat (HIV LTR; Rosen et al. 1985), immediately $5^{\prime}$ to the bacterial CAT gene linked to the SV40 splice and poly(A) sites (from pSV2 CAT; Gorman et al. 1982) in pGEM-1 (Promega) (construction described in Lew et al. 1991). The APF1-HIV-CAT reporter construct consisted of two APFl oligonucleotides in direct repeat cloned into the Smal site of the pGEM polylinker (17 bp from the HIV LTR) of HIV-CAT. The HNF-4 expression vectors (sense, pLEN4S, and antisense, pLEN4A) were constructed by cloning the entire $3-\mathrm{kb}$ HNF- 4 cDNA of pf 7 into the BamHI site of pLEN (courtesy of Cal-Bio, Inc.) pLEN is a $\sim 5-\mathrm{kb}$ expression vector containing the SV40 enhancer (1120-bp, HindIII fragment), the human metallothionein promoter (836-bp, HindIII-BamHI fragment), and human growth hormone 3 '-untranslated region ( $\sim 550-\mathrm{bp}, B a m \mathrm{HI}-E c o R I$ fragment) in pUC8.

DNA transfections and $\beta$-galactosidase and CAT assays were performed essentially as in Sambrook et al. (1989). DNA was transfected into HeLa cells, grown in Dulbecco's modified Eagle medium (DMEM, GIBCO) plus $10 \%$ bovine calf serum (BCS, Hyclone), using the calcium phosphate method: A precipitate of HNF-4 expression vector (pLEN4S or PLEN4A, $0-5 \mu \mathrm{g}$ ), $1 \mu \mathrm{g}$ pCMV- $\beta$-gal (internal control; MacGregor and Caskey 1989), $2 \mu \mathrm{g}$ reporter construct (HIV-CAT or APFI/HIV/CAT), and $50 \mu \mathrm{g}$ denatured sonicated salmon sperm DNA were added to cells $60-80 \%$ confluent in a $100-\mathrm{mm}$ dish. After $15 \mathrm{hr}$ at $37^{\circ} \mathrm{C}$, the cells were treated with a glycerol shock $(15 \%)$ and incubated for $48 \mathrm{hr}$ at $37^{\circ} \mathrm{C}$ in DMEM plus $10 \%$ BCS and $10 \mathrm{~mm}$ sodium butyrate (to enhance expression from the SV40 enhancer; Gorman et al. 1983). Extracts were prepared, normalized to $\beta$-galactosidase activity, and assayed for CAT activity $\left(20 \mathrm{hr}\right.$ incubation at $\left.37^{\circ} \mathrm{C}\right)$.

\section{Northern blot analysis}

Total RNA was extracted from male rat (Sprague-Dawley) tissue using the acid phenol method of Chomczynski and Sacchi (1987), as modified by Puissant and Houdebine (1990). Poly $(\mathrm{A})^{+}$RNA was selected on oligo(dT)-cellulose columns and electrophoresed (5 $\mu \mathrm{g} /$ lane) in a $1 \%$ agarose-formaldehyde gel as described in Sambrook et al. (1989). The RNA was transferred to Immobilon- $N$ (Millipore) and probed according to the protocol provided by the manufacturer. HNF-4 mRNA was detected with a random-primed cDNA fragment containing nucleotides 616-1114 (the hatched area in Fig. 3, top). The highstringency wash was with $0.2 \times$ SSC, $0.1 \%$ SDS at $60^{\circ} \mathrm{C}$ for 15 $\min$. The autoradiograph with the HNF-4 probe was exposed for 3 days with two intensifying screens. rRNA (28S and 18S, 4.9 and $1.9 \mathrm{~kb}$, respectively/ was used as size markers.

\section{HNF-4 antiserum and mobility shift analysis}

A peptide (445, $\mathrm{NH}_{2}$-Cys-Pro-Gln-Pro-Thr-Ile-Thr-Lys-GlnGlu-Val-Ile-COOH| was synthesized that corresponded to amino acids $445-455$ of the rat HNF-4 protein (Fig. 2B), except that $\mathrm{Ala}_{454}$ was substituted for valine, which is found in the mouse protein at that position, and a cysteine was added to the amino terminus for the purposes of coupling. Peptide 445 was linked to keyhole limpet hemocyanin (Calbiochem) via maleimidobenzoyl- $N$-hydroxy succinimide ester (Pierce) at $\mathrm{pH} 7.0$ as in Green et al. (1982). A New Zealand white rabbit was injected subcutaneously with $\sim 0.6 \mathrm{mg}$ of linked peptide and boosted twice with $\sim 0.3 \mathrm{mg}$ of linked peptide using standard procedures (Harlow and Lane 1988). One microliter of the antiserum, diluted 10 -fold in $3 \%$ BSA plus $0.02 \%$ sodium azide in a saline solution, was added to $14 \mu \mathrm{l}$ of shift reaction halfway through the reaction lat ambient temperaturel. The reaction was analyzed on a mobility-shift gel as described above.

\section{Acknowledgments}

We thank $S$. Karanthanasis for providing the nucleotide sequence of Arpl cDNA before it was published, R.M. Evans for kindly supplying the ERE and TRE oligonucleotides, O. Litvin for expert technical assistance, D. Atherton and the Protein Sequencing Facility for amino acid sequence and peptide synthesis, J. Cromlich for guidance with HPLC, and A. English for help with the manuscript. F.M. Sladek is a postdoctoral fellow from the American Cancer Society (grant PF-3232). This work was supported by a grant from National Institutes of Health.

The publication costs of this article were defrayed in part by payment of page charges. This article must therefore be hereby marked "advertisement" in accordance with 18 USC section 1734 solely to indicate this fact.

\section{References}

Baumhueter, S., D.B. Mendel, P.B. Conley, C.J. Kuo, C. Turk, M.K. Graves, C.A. Edwards, G. Courtois, and G.R. Crabtree. 1990. HNF-1 shares three sequence motifs with the POU domain proteins and is identical to LF-Bl and APF. Genes Dev. 4: $372-379$

Beato, M. 1989. Gene regulation by steroid hormones. Cell 56: $335-344$

Birkenmeier, E.H., B. Gwynn, S. Howard, J. Jerry, J.I. Gordon, W.H. Landschulz, and S.L. McKnight. 1989. Tissue-specific expression, developmental regulation and mapping of the gene encoding CCAAT/enhancer binding protein. Genes Dev. 3: 1146-1156.

Brand, N., M. Petkovich, A. Krust, P. Chambon, H. de The, A. Marchio, P. Tiollais, and A. Dejean. 1988. Identification of a second human retinoic acid receptor. Nature 332: 850-853.

Breslow, J. 1988. Apolipoprotein genetic variation and human disease. Physiol. Rev. 68: 85-132.

Chomczynski, P. and N. Sacchi. 1987. Single-step method of RNA isolation by acid guanidinium thiocyanate-phenolcholoform extraction. Anal. Biochem. 162: 156-159.

Costa, R.H., D.R. Grayson, K.G. Xanthopoulos, and J.E. Darnell Ir. 1988. A liver-specific DNA-binding protein recognizes multiple nucleotide sites in regulatory regions of transthyretin, $\alpha$ l-antitrypsin, albumin, and simian virus 40 genes. Proc. Natl. Acad. Sci. 85: 3840-3844.

Costa, R.H., D.R. Grayson, and J.E. Darnell Jr. 1989. Multiple hepatocyte-enriched nuclear factors function in the regulation of transthyretin and $\alpha \mathrm{l}$-antitrypsin genes. Mol. Cell. Biol. 9: $1415-1425$.

Costa, R.H., T.A. Van Dyke, C. Yan, F. Kuo, and J.E. Darnell, Jr. 1990. Similarities in transthyretin gene expression and differences in transcription factors: Liver and yolk sac com- 
pared to choroid plexus. Proc. Natl. Acad. Sci. 87: 65896593.

Courtois, G., J.G. Morgau, L.A. Campbell, G. Fourel, and G.R. Crabtree. 1987. Interaction of a liver-specific nuclear factor with the fibrinogen and $\alpha 1$-antitrypsin promoters. Science 238: $688-692$.

Danielsen, M., L. Hinck, and G.M. Ringold. 1989. Two amino acids within the knuckle of the first zinc finger specify DNA response element activation by the glucocorticoid receptor. Cell 57: 1131-1138.

Derman, E., K. Krauter, L. Walling, C. Weinberger, M. Ray, and J.E. Darnell, Jr. 1981. Transcriptional control in the production of liver-specific mRNAs. Cell 23: 731-739.

de The, H., A. Marchio, P. Tiollais, and A. Dejean. 1987. A novel steroid thyroid hormone receptor-related gene inappropriately expressed in human hepatocellular carcinoma. Nature 330: 667-670.

Evans, R.M. 1988. The steroid and thyroid hormone receptor superfamily. Science 240: $889-895$.

Fawell, S.E., J.A. Lees, R. White, and M.G. Parker. 1990. Characterization and colocalization of steroid binding and dimerization activites in the mouse estrogen receptor. Cell 60: $953-962$.

Feinberg, A.P. and B. Vogelstein. 1983. A technique for radiolabeling DNA restriction endonuclease fragments to high specific activity. Anal. Biochem. 132: 6-13.

Forman, B.M. and H.H. Samuels. 1990. Interactions among a subfamily of nuclear hormone receptors: The regulatory zipper model. Mol. Endocrinol. 4: 1293-1301.

Forman, B.M., C.-R. Yan, M. Au, J. Casanova, J. Ghysdael, and H.H. Samuels. 1989. A domain containing leucine-zipperlike motifs mediate novel in vivo interactions between the thyroid hormone and retinoic acid receptors. Mol. Endocrinol. 3: 1610-1626.

Frain, M., G. Swart, P. Monaci, A. Nicosia, S. Stampfli, R. Frank, and R. Cortese. 1989. The liver-specific transcription factor LF-Bl contains a highly diverged homeobox DNA binding domain. Cell 59: 145-157.

Fried, M. and D.M. Crothers. 1981. Equilibria and kinetics of lac repressor-operator interactions by polyacrylamide gel electrophoresis. Nucleic Acids Res. 9: 6505-6525.

Giguere, V., N. Yang, P. Segui, and R.M. Evans. 1988. Identification of a new class of steroid hormone receptors. Nature 331: $91-94$.

Glass, C.K., S.M. Lipkin, O.V. Devary, and M.G. Rosenfeld. 1989. Positive and negative regulation of gene transcription by a retinoic acid-thyroid hormone receptor heterodimer. Cell 59: 697-708.

Gorman, C.M., L.F. Moffat, and B.H. Howard. 1982. Recombinant genomes which express chloramphenicol acetyltransferase in mammalian cells. Mol. Cell. Biol. 2: 1044-1051.

Gorman, C.M., B.H. Howard, and R. Reeves. 1983. Expression of recombinant plasmids in mammalian cells is enhanced by sodium butyrate. Nucleic Acids Res. 11: 7631-7648.

Gorski, K., M. Carneiro, and U. Schibler. 1986. Tissue-specific in vitro transcription from the mouse albumin promoter. Cell 47: 767-776.

Green, N., H. Alexander, A. Olson, S. Alexander, T.M. Shinnick, J.G. Sutcliffe, and R.A. Lerner. 1982. Immunogenic structure of the influenza virus hemagglutinin. Cell 28: 477-487.

Green, S. and P. Chambon. 1988. Nuclear receptors enhance our understanding of transcription regulation. Trends Genet. 4: 309-314

Green, S., P. Walter, V. Kumar, A. Krust, J.-M. Bornert, P. Argos, and P. Chambon. 1986. Human oestrogen receptor
cDNA: Sequence, expression and homology to v-erb-A. Nature 320: 134-139.

Hamada, K., S.L. Gleason, B.-Z. Levi, S. Hirschfeld, E. Appella, and K. Ozato. 1989. H-2RIIBP, a member of the nuclear hormone receptor superfamily that binds to both the regulatory element of major histocompatibility class I genes and the estrogen response element. Proc. Natl. Acad. Sci. 86: 82898293.

Hardon, E.M., M. Frain, G. Paonessa, and R. Cortese. 1988. Two distinct factors interact with the promoter regions of several liver-specific genes. EMBO I. 7: 1711-1719.

Harlow, E. and D. Lane. 1988. Antibodies: A laboratory manual. Cold Spring Harbor Laboratory, Cold Spring Harbor, New York.

Ito, Y., N. Azrolan, A. O'Connell, A. Walsh, and J.L. Breslow. 1990. Hypertriglyceridemia as a result of human apoCII gene expression in transgenic mice. Science 249: 790-793.

Johnson, P.F. 1990. Transcriptional activators in hepatocytes. Cell Growth Differ. 1: 47-52.

Johnson, P.F., W.H. Landschulz, B.J. Graves, and S.L. McKnight. 1987. Identification of a rat liver nuclear protein that binds to the enhancer core element of three animal viruses. Genes Dev. 1: 133-146.

Kadonaga, J.T. and R. Tijian. 1986. Affinity purification of sequence-specific DNA binding proteins. Proc. Natl. Acad. Sci. 83: 5889-5893.

Kozak, M. 1987. An analysis of 5 '-noncoding sequences from 699 vertebrate messenger RNA's. Nucleic Acids Res. 15: $8125-8143$.

Krebs, E., R. Eisenman, E. Kuenzel, D. Litchfield, F. Lozeman, B. Lischer, and I. Sommercorn. 1988. Casein kinase II as a potentially important enzyme concerned with signal transduction. In Molecular biology of signal transduction, pp. 77-84. Cold Spring Harbor Laboratory, Cold Spring Harbor, New York.

Kumar, V. and P. Chambon. 1988. The estrogen receptor binds tightly to its responsive element as a ligand-induced homodimer. Cell 55: 145-156.

Kuo, C.F., K.G. Xanthopoulos, and J.E. Darnell Jr. 1990. Fetal and adult localization of C/EBP: Evidence for combinatorial action of transcription factors in cell-specific gene expression. Development 109: 473-481.

Lai, E., V.R. Prezioso, E. Smith, O. Litvin, R.H. Costa, and J.E. Darnell Jr. 1990. HNF-3A, a hepatocyte-enriched transcription factor of novel structure is regulated transcriptionally. Genes Dev. 4: 1427-1436.

Landschulz, W.H., P.F. Johnson, E.Y. Adashi, B.J. Graves, and S.L. McKnight. 1988. Isolation of a recombinant copy of the gene encoding C/EBP. Genes Dev. 2: 786-800.

Lathe, E. 1985. Synthetic oligonucleotide probes deduced from amino acid sequence data: Theoretical and practical considerations. J. Mol. Biol. 183: $1-12$.

Leff, T., K. Reue, A. Melian, H. Culver, and J.L. Breslow. 1989. A regulatory element in the ApoCIII promoter that directs hepatic specific transcription binds to proteins in expressing and nonexpressing cell types. I. Biol. Chem. 264: 1613216137.

Lew, D.J., T. Decker, I. Strehlow, and J.E. Darnell. 1991. Overlapping elements in the GBP gene promoter mediate transcriptional induction by alpha and gamma-interferon. Mol. Cell Biol. (in press).

Li, Y., R.-F. Shen, S.Y. Tsai, and S.L.C. Woo. 1988. Multiple hepatic trans-acting factors are required for in vitro transcription of the human alpha-1-antitrypsin gene. Mol. Cell. Biol. 8: $4362-4369$.

MacGregor, G.R. and C.T. Caskey. 1989. Construction of 
plasmids that express E. coli $\beta$-galactosidase in mammalian cells. Nucleic Acids Res. 17: 2365.

Mader, S., V. Kumar, H. de Verneuil, and P. Chambon. 1989. Three amino acids of the oestrogen receptor are essential to its ability to distinguish an oestrogen from a glucocorticoidresponsive element. Nature 338: 271-274.

Mangelsdorf, D.J., E.S. Ong, J.A. Dyck, and R.M. Evans. 1990. Nuclear receptor that identifies a novel retinoic acid response pathway. Nature 345: 224-229.

Maniatis, T., E.F. Fritsch, and J. Sambrook. 1982. Molecular cloning: A laboratory manual. Cold Spring Harbor Laboratory, Cold Spring Harbor, New York.

Matsudaira, P. 1987. Sequence from picomole quantities of proteins electroblotted onto polyvinylidene difluorid membranes. J. Biol. Chem. 262: 10035-10038.

McKnight, G.S. and R.D. Palmiter. 1979. Transcriptional regulation of the ovalbumin and conalbumin genes by steroid hormones in chick oviduct. J. Biol. Chem. 254: 9050-9058.

Mermod, N., E.A. O'Neill, T.J. Kelly, and R. Tjian. 1989. The proline-rich transcriptional activator of CTF/NF-1 is distinct from the replication and DNA binding domain. Cell 58: $741-753$.

Miyajiima, N., Y. Kadowaki, S. Fukushige, S. Shiminizu, K. Semba, Y.H. Yamanashi, K. Matsubara, K. Toyoshima, and T. Yamanoto. 1988. Identification of two novel members of erbA superfamily by molecular cloning: The gene products of the two are highly related to each other. Nuceic Acids Res. 16: 11057-11074.

Monaci, P., A. Nicosia, and R. Cortese. 1988. Two different liver-specific factors stimulate in vitro transcription from the human $\alpha$-antitrypsin promoter. EMBO /. 7:20752087.

Mueller, C.R., P. Maire, and U. Schibler. 1990. DBP, a liverenriched transcriptional activator, is expressed late in ontogeny and its tissue specificity is determined posttranscriptionally. Cell 61: 279-291.

Pearson, W.R. and D.J. Lipman. 1988. Improved tools for biological sequence comparison. Proc. Natl. Acad. Sci. 85: $2444-$ 2448.

Puissant, C. and L.-M. Houdebine. 1990. An improvement of the single-step method of RNA isolation by acid guanidinium thiocyanate-phenol-chloroform extraction. BioTechniques 8: 148-149.

Reue, K., T. Leff, and J.L. Breslow. 1988. Human apolipoprotein CIII gene expression is regulated by positive and negative Cis-acting elements and tissue-specific protein factors. 1 . Biol. Chem. 263: 6857-6864.

Rosen, C.A., J.G. Sodroski, and W.A. Haseltine. 1985. The location of cis-acting regulatory sequenes in the human $\mathrm{T}$ cell lymphotropic virus type III (HTLV-III/LAV) long terminal repeat. Cell 41: 813-823.

Ruppert, S., M. Boshart, F.X. Bosch, W. Schmid, R.E.K. Fournier, and G. Schutz. 1990. Two genetically defined transacting loci coordinately regulate overlapping sets of liverspecific genes. Cell 61: 895-904.

Ryseck, R.-P., H. Macdonald-Bravo, M.-G. Mattei, S. Ruppert, and R. Bravo. 1989. Structure, mapping and expression of a growth factor inducible gene encoding a putative nuclear hormonal binding receptor. EMBO I. 8: 3327-3335.

Saiki, R.K., D.H. Gelfand, S. Stoffel, S.J. Scharf, R. Higuchi, G.T. Horn, K.B. Mullis, and H.A. Erlich. 1988. Primer-directed enzymatic amplification of DNA with a thermostable DNA polymerase. Science 239: 487-491.

Sambrook, J., E.F. Fritsch, and T. Maniatis. 1989. Molecular cloning: A laboratory manual. Cold Spring Harbor Laboratory Press, Cold Spring Harbor, New York.
Sanger, F., S. Nicklen, and A.R. Coulson. 1977. DNA sequencing with chain terminating inhibitors. Proc. Natl. Acad. Sci. 74: 5463-5467.

Schule, R., K. Umesono, D.J. Mangelsdorf, J. Bolado, J.W. Pike, and R.M. Evans. 1990. Jun-fos and receptors for vitamins A and $D$ recognize a common response element in the human osteocalcin gene. Cell 61: 497-504.

Tsai, S.Y., J. Carlstedt-Duke, N.L. Weigel, K. Dahlman, J.-A. Gustafsson, M.-J. Tsai, and B.W. O'Malley. 1988. Molecular interactions of steroid hormone receptor with its enhancer element: Evidence for receptor dimer formation. Cell 55: $361-369$.

Umesono, K. and R.M. Evans. 1989. Determinants of target gene specificity for steroid/thyroid hormone receptors. Cell 57: $1139-1146$

Umesono, K., V. Giguere, C.K. Glass, M.G. Rosenfeld, and R.M Evans. 1988. Retinoic acid and thyroid hormone induce gene expression through a common responsive element. Nature 336: 262-265.

Vaulont, S., N. Puzenat, A. Kahn, and M. Raymondjean. 1989. Analysis by cell-free transcription of the liver-specific pyruvate kinase gene promoter. Mol. Cell. Biol. 9: 4409-4415

Wang, L.-H., S.Y. Tsai, R.G. Cook, W.G. Beattie, M.-J. Tsai, and B.W. O'Malley. 1989. COUP transcription factor is a member of the steroid receptor superfamily. Nature 340: $163-166$.

von der Ahe, D., S. Janich, C. Scheidereit, R. Renkawitz, G. Schutz, and M. Beato. 1985. Glucocorticoid and progesterone receptors bind to the same sites in two hormonally regulated promoters. Nature 313: 706-709.

Weinberger, C., C.C. Thompson, E.S. Ong, R. Lebo, D.J. Gruo, and R.M. Evans. 1986. The c-erb-A gene encodes a thyroid hormone receptor. Nature 234: 641-646.

Wingender, E. 1990. Transcription regulating proteins and their recognition sequences. Crit. Rev. Eukaryotic Gene Expression 1: 11-48.

Xanthopoulos, K.G., J. Mirkovitch, T. Decker, C.F. Kuo, and J.E. Darnell Jr. 1989. Cell-specific transcriptional control of the mouse DNA-binding protein $\mathrm{mC} / \mathrm{EBP}$. Proc. Natl. Acad. Sci. 86: 4117-4121. 


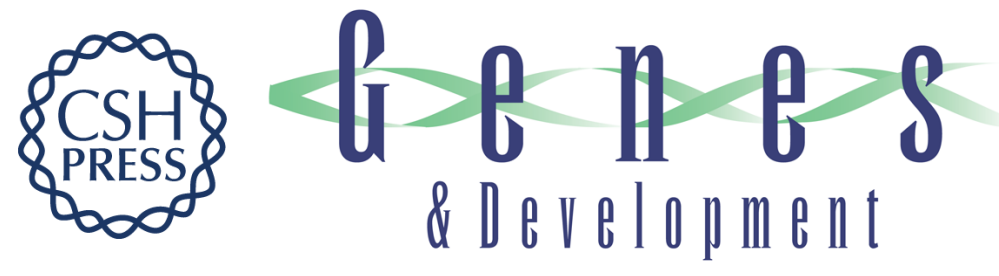

\section{Liver-enriched transcription factor HNF-4 is a novel member of the steroid hormone receptor superfamily.}

F M Sladek, W M Zhong, E Lai, et al.

Genes Dev. 1990, 4:

Access the most recent version at doi:10.1101/gad.4.12b.2353

References This article cites 69 articles, 25 of which can be accessed free at:

http://genesdev.cshlp.org/content/4/12b/2353.full.html\#ref-list-1

License

Email Alerting

Service

Receive free email alerts when new articles cite this article - sign up in the box at the top right corner of the article or click here.

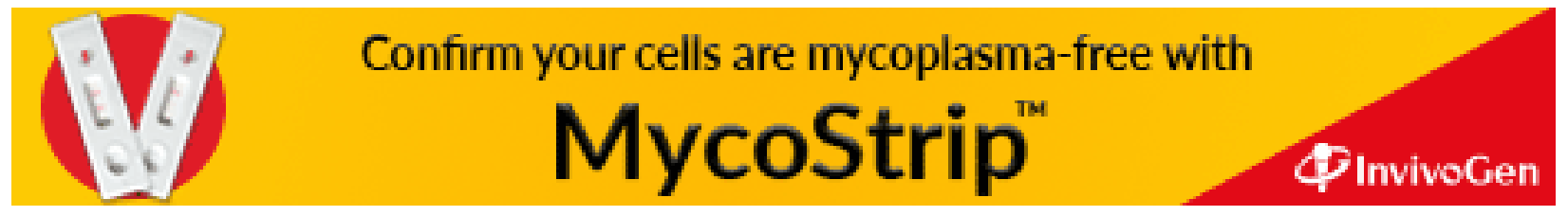

